\title{
History of a Strategy to Eradicate Poliomyelitis in Uruguay and Argentina ${ }^{1}$
}

\author{
Adriana Alvarez
}

\section{Introduction}

he outbreak of poliomyelitis in the early 1950 s turned it into one of the most
feared diseases in the twentieth century. The resulting deaths and the
thousands of children and adults who were handicapped world-wide made it a real threat which was only controlled with the introduction of the vaccines developed by Jonas Salk and Albert Sabin.

This paper addresses the different health policies applied on both banks of the River Plate, starting in the 1950s. Soon after that, several Latin American countries, among which were Argentina and Uruguay, started oral vaccination programs. This paper attempts to answer questions related to the characteristics of the vaccination programs in each of the two countries and their relation to the degree in which the disease affected each of them. It is part of a more extensive research project dealing with the social, political and cultural consequences of the polio epidemics in twentieth-century Argentina with a view to understanding what happened in order to explain the present Post-Polio Syndrome (PPS).

Research has helped to reveal that the original project had to be reviewed since, unlike other pathologies, poliomyelitis shared similar events and circumstances in several Latin American countries, at least up to mid-twentieth century, and so it was necessary to connect the processes. Although Latin American countries have generally shown great progress in consolidating the history of health and disease, in the current research there is a tendency to priorize regional and/or local aspects, thus losing sight of the contexts within which the processes developed.

Less than a decade ago, Serge Gruzinski supported the idea that the historian should have a broader vision of history, beyond the nation, and proposed that 'connections' ${ }^{2}$ since histories are multiple, plural, are connected among each other and can intercommunicate.

1 Translated by Cecilia Chapman.

2 Gruzinski Serge "Les mondes melés de la Monarchie catholique et autres connected histories”. Annales: Histoire, Sciences Sociales 56 (2001), 85-117. 
The 2006 publication in the American Historical Review magazine has been particularly stimulating to this paper, because it presents the idea that transnational history is not closed to any particular methodological viewpoint. Political history can be transnational, as can be cultural history, entrepreneurial history or the history of health and disease, since the emphasis is on observing the objects of research keeping an open mind regarding different methodological preferences and problems, and highlighting networks, processes, beliefs and institutions beyond the national sphere.

According to Isabel Hofmeyr, the key to understanding transnational history is its central concern with movements and circulations. Topics considered for transnational history are connected especially to social and/or political diaspora, to movements of groups of goods or people. I would add to this list pests and epidemics, such as that of poliomyelitis, which spread on both banks of the River Plate regardless of political boundaries.

This perspective led to the rise of several questions concerning the development of polio in countries neighboring Argentina, the answers to which might shed more light on the explanations arrived at in the national sphere. On this occasion, the vaccination campaigns in Argentina and Uruguay in the 1950s and 1960s will be dealt with, since they were the necessary previous steps to the eradication of polio some decades later.

Argentina and Uruguay, thanks to their geographical vicinity basically in the area of the River Plate, which outlines a border extending some 500 kilometers, are countries whose destinies have been intertwined since their origins. Although their sizes are different, both regarding geographical extension and demography, Uruguay shares the same climate and soil as that of the Argentine pampa area.

Map 1. Border between Argentina and Uruguay.
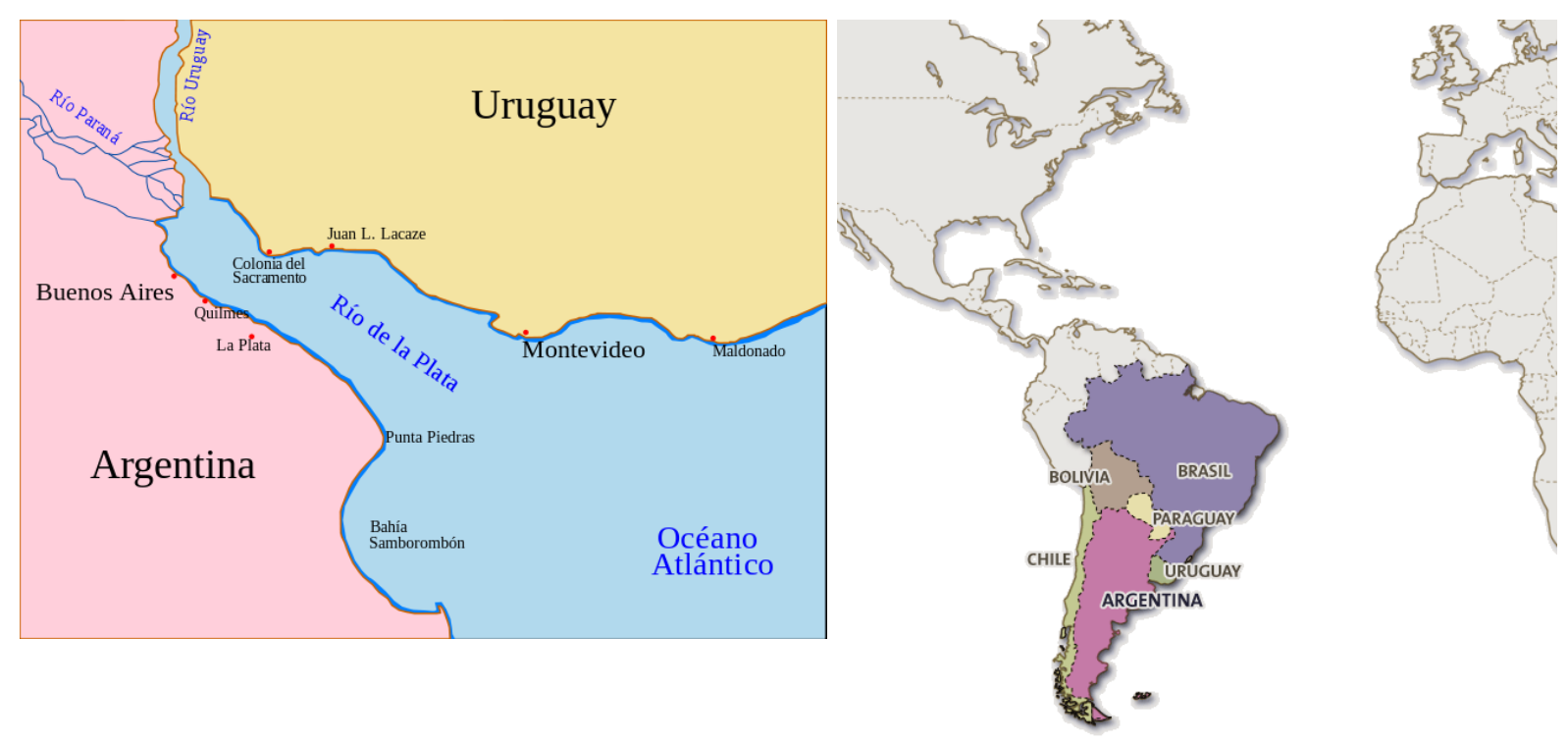
It is possible that their shared origin or the geographical vicinity can explain common patterns in political and health-policy development, as well as some differences stemming from the different realities each of these two countries had and have. The epidemiologic scenario must be understood within this frame.

\section{When Smiles Faded}

Both Argentina and Uruguay were considered prosperous and modern countries within Latin America, with open economies based on farming, which around midtwentieth century sought to strengthen their industries by substituting local for imported goods. On the other hand, both states had achieved an epidemiological transition which had mostly controlled infectious diseases, leaving the stage to circulatory, cardiovascular and other diseases. This was the result of multiple causes such as sanitary and economic improvements, new social practices and others. From a broader perspective it could be said that the states reached this stage with the development of the welfare state. ${ }^{3}$ However, the first slump in infant mortality in Uruguay goes back to the first decade of the twentieth century when it reached the lowest rates for the times, only matched by Norway and Sweden, and it takes place during the start and consolidation of Batlle's welfare model. ${ }^{4}$ Likewise, the persistence of high infant mortality rates in the Argentine hinterland in the mid-twentieth century leads to the consideration that, leaving aside the perceptions of the time, those "Welfare States" showed inconsistencies which were put to the test with the appearance of the polio epidemics, revealing that the actions the state took were ineffective.

Both Argentina and Uruguay had experienced sporadic outbursts of polio ${ }^{5}$ since the start of the twentieth century ${ }^{6}$ but it was only in the 1950s that the disease struck a large number of people, causing fear among the population at large.

3 Pellegrino, Adela. 2003. Caracterización demográfica del Uruguay. Montevideo. UNFPAFacultad de Ciencias Sociales-Universidad de la República, Uruguay.

4 Birn, A.E., W. Cabella and R. Pollero. 2005. "La mortalidad infantile uruguaya en la primera mitad del siglo XX: un análisis por causas del pasado al presente." In VII Jornadas Argentinas de Estudios de Población (Asociación de Estudios de Población de la Argentina),2003, I: 37-154, Universidad Nacional de Tucumán. Tafí del Valle. Tucumán. On this topic also see Birn, A.E., R. Pollero and W. Cabella. 2003. "No se debe llorar sobre leche derramada. El Pensamiento Epidemiológico y la Mortalidad Infantil en Uruguay, 1900-1940.” Estudios Interdisciplinarios de América Latina y el Caribe 1(1) 35-65.

5 The etiologic agent, a virus which spreads through contact with feces, was known since the thirties of the previous century, but its control was unknown.

6 Alvarez Adriana "El impacto de los brotes de poliomielitis en las formas de organización ciudadana (Buenos Aires)“ Revista de Historia de la medicina y epistemología médica vol .V N 1-1 semestre de 2013 (ISSN 1852-6152, 2013. 
The alarm was raised in the 1940s by the international events reflected in the main Uruguayan and Argentine newspapers, which portrayed the interest in and astonishment caused by the intensification of the disease in countries such as the United States and Canada, as well as by the local cases, which were increasing in number. Thus, by the 1940s polio was a health problem in both Argentina and Uruguay.

The following table shows that from the mid-1940s, polio had a variable but steady presence both in Argentina and in Uruguay, with Argentina showing a rise between 1945 and 1949 while Uruguay shows a fall in cases, even though the most serious epidemics took place in the following decade.

Table 1. Number of reported cases of poliomyelitis with rates per 100,000 inhabitants in Argentina and Uruguay, from 1945 to 1949

\begin{tabular}{|l|c|c|}
\hline YEAR & ARGENTINA & URUGUAY \\
\hline 1945 & 2,5 & 8 \\
\hline 1946 & 4,2 & 2,6 \\
\hline 1947 & 2,9 & 5,6 \\
\hline 1948 & 3,4 & 0,4 \\
\hline 1949 & 6,6 & 0,9 \\
\hline
\end{tabular}

Sources: Obtained from the Boletín de la Oficina Panamericana Año 34, vol. XXXVIII, Junio 1955, n 6

Children were at risk of dying or suffering the consequences of infantile paralysis. In Uruguay, during the period between July 1950 and June 301954 there were 248 reported cases of polio, according to the official records of the Ministry of Public Health. However, in the twelve following months, from July 10, 1954 to June 30, 1955, there were 550 reported cases which, in a country of 2.6 million inhabitants, constituted a serious epidemic, with an attack rate of 21 out of every 100,000 inhabitants. ${ }^{7}$ In the case of Argentina, the 1950s had started with only isolated cases in the city of Buenos Aires and the province of Santa Fe. In 1953 these figures shot up, affecting 2579 people, of which 1,300 belonged to Buenos Aires, followed in quantity by the provinces of Santa Fe, Tucumán and Córdoba. In the face of this situation, the provincial governments also responded and in the province of Santa $\mathrm{Fe}$, a Commission for the Defense against and Prevention of Poliomyelitis was

7 Leunda, J. J., and others: Mass vaccination program with live, attenuated poliomyelitis virus in Montevideo, Uruguay. Live Poliovirus Vaccines: Papers Presented and Discussions Held at the First International Conference on Live Poliovirus Vaccines, Organización Panamericana de la Salud, Publicación Científica No 44, Washington D.C., 1959, pp 638-646. 
created to organize the fight against the disease in the face of the outbreak in the city of Rosario. Medical and political concern for the consequences of this disease did not lie so much on the death rate (179 deceased) as on the disabilities it produced (1316 handicapped victims) in the younger members of the population. Seventy-one percent of patients were children between zero and four years of age. ${ }^{8}$ Cases began to be reported by the press in the month of January, and the number of infected victims rose. Up to then and until the appearance of the vaccine in 1955, measures were only palliative.

Some report says that:

...cleaning tasks were organized in towns and cities, triggered by the belief that the virus was 'in the air'. Neighbors chose spontaneously to clean up vacant lots and weed out gardens. Houses smelled of bleach and phenol, and camphor bags emerged from children's clothes, emitting their typical pungent smell... Any method or suggestion was adopted with alacrity to prevent contagion. It was common to see whitewashed walls and trees, which gave them a ghostly appearance. White bands on tree trunks were in place for many years, even when the epidemics had been forgotten thanks to the compulsory vaccination programs ..."

Such testimonies show that both countries lacked resources and health policies to face the outbreak of the disease, among other reasons because, in spite of the concern with which cases in other countries were viewed, the lack of serious local epidemic outbreaks meant that there were no plans for any assistance network to combat them. On both sides of the River Plate, during the years when the epidemic struck, specific spaces had to be improvised such as wards in hospitals or emergency rooms in neighborhoods. This absence of previous planning was criticized by the government opposition groups, since on both banks of the River Plate critics referred to the "political paralysis" exhibited by the governments of the two countries when dealing with the outbreaks of polio.

\section{Infantile Paralysis and Political Paralysis. Years of Confusion}

Which were the health models applied in Argentina and Uruguay in the years prior to the great polio epidemics? As mentioned before, from the start of the twentieth

8 In April 1949 there had been one case of infantile paralysis in the city of Buenos Aires, informed by the Ministry of Public Health on 21 April 1949. Memoria. Op.cit.: 312. Between the months of April and July 1951 there were cases of polio in the city of Buenos Aires and in the Province of Santa Fe. See Resolución No 36.181, 5 July 1951 in Memoria. Op. cit: 405.

9 Interview to María Angelina Sánchez, affected by the 1956 polio epidemics. Diario Clarin 27/7/2013 http://www.clarin.com/sociedad/epidemia-polio-marco-siempre 0 959304181.html 
century "infantile paralysis" was known in both banks of the River Plate, which means that by mid-century it was not an unknown disease either to doctors or to society at large. However, the outbreak was regarded with fear, surprise and puzzlement, as it took place at a time when the government, within a welfare state frame, had taken great health improvement measures in both countries.

Uruguay pioneered (with respect to Argentina) in adopting health reforms, based on a centralizing action of the state through the creation, in 1934, of the Ministry of Public Health, which unified the National Hygiene Council (a regulatory body) and the National Public Assistance (a health-care body). ${ }^{10}$ The new Ministry centralized health policies and was the sole organizing body for the whole of the Uruguayan territory. Among its functions was the control of plagues and epidemics and the prevention of diseases. ${ }^{11}$ This initiative was the result of the concentration of power carried out by the Terra regime (1933-1938) ${ }^{12}$ within the framework of the 1934 Constitutional Reform which attempted the "foundation of the Third Republic." This was a moderately conservative movement but it carried out important innovations such as the Food Institute, the Housing Institute, the reorganization of Public Health and the promotion of the Children's Code.

Subsequently, during the neo-Batlle period (roughly between 1940 and 1960) there were a series of important institutional transformations such as the changes in the etiological models which organized the field of health knowledge, the institutional changes such as the emergence of new organizational spaces in health care, the training of new health agents under the strong influence of international agencies in the consolidation of management models and in the role of the different categories of professionals in health care. ${ }^{14}$ Thus, the creation of public health policies, together with the signing of several international agreements in the field of health care and prevention, led to the creation of many health centers. Their origin can be found in a context of development in Uruguay of health-care preventive strategies and in the consolidation of international agreements both bilateral and with multilateral agencies. The health centers were defined as spheres institutionally devoted to the prevention of disease and the promotion of health care and must be located within a pan-American post-war strategy under the hegemony of the United

10 Portillo, José. "Historia de la medicina estatal en Uruguay (1724-1930)". Rev Med Uruguay 1995, 11:5-18

11 Margolis, E., N. Piaza. Organización de la atención médica en el Uruguay. Montevideo. Nordan, 1989.

12 Gabriel Terra was elected to the Presidency of Uruguay for the period 1934-1938.

13 The presidents during this period were Alfredo Baldomir (1938-1943), Juan José Amezaga (1943-1947) and Luis Batlle (1947-1958)

14 Ortega, Elizabeth; Mitiavila, Myriam Raquel. Preventismo sanitarista y la institucionalización del Trabajo Social en el Uruguay neobatllista: una indagación genealógica. Revista Katálysis, vol. 8, núm. 2, Julio-diciembre 2005, pp. 211-224. Universidade Federal de Santa Catarina, Santa Catarina, Brasil. 
States and parallel to the creation of international agencies which became essential in developing key programs. ${ }^{15}$ In spite of all this, as will be seen below, this new Statemonitored sanitary map was incapable of either containing the poliomyelitis outbreaks which struck Uruguay or of coping with their after-effects. Rehabilitation of victims suffering from after-effects of polio was carried out, as also happened in Argentina, by physicians who had had training in United States hospitals and had become acquainted with the so-called Rehabilitation Centers, which were built locally thanks to community volunteer work. In Uruguay, the Recovery Center for Handicapped Children was founded by Dr. Ricardo Cariat Larrar not as part of a state policy but as part of a citizen project.

Argentina created the Ministry of Health after the Constitutional Reform of 1949 and the 13,259 Ministry Law, that is, belatedly with respect to Uruguay. The State's role regarding health was divided into three distinct branches: medical attention, sanitary medicine and social medicine. A structure of geographical de-centralization was built within these fields of work and the country was divided into regional centers which, due to the physical characteristics of Argentina (size and communications networks) sought action coordinated with a greater field of autonomy in the operational headquarters.

A national program of hospital building, as established by Law 13,019, was carried out together with the regional organization, as part of the National Health Plan ${ }^{16}$ which in turn was included in the First Five-Year Plan which Peronism enthroned in its quest to consolidate the image of a central State, and with some characteristics similar to those stated for Uruguay.

\section{In between Political Crises and Poliomyelitis Outbreaks}

In mid-twentieth century, Juan Domingo Perón, in Argentina, and Luis Batlle Berres, in Uruguay, were responsible for setting up a strong central State, controlling not only economic aspects but also social ones, and both gave a leading role to working sectors. Public policies in general and health care policies in particular were the offspring of this model of state embodied by both Perón and Batlle.

15 Ortega, Elizabeth; Mitiavila; Myriam Raquel. Preventivismo sanitarista y la institucionalización del Trabajo Social en el Uruguay neobatllista: una indagación genealógica. Revista Katálysis, vol. 8, núm.2, Julio-diciembre 2005, pp. 211-224. Universidade Federal de Santa Catarina. Santa Catarina, Brasil, p. 214.

16 ORGANIZACION SANITARIA PANAMERICANA. Decimotercera Conferencia Sanitaria Panamericana. Comité Regional. Organización Mundial de la Salud. Ciudad Trujillo, República Dominicana. Octubre 1-10 de 1960. Publicación No 261 Anexo o, Septiembre, 1952. Oficina Regional de la Organización Mundial de la Salud. Washington D.C., E.U.A. 
The great outbreaks of poliomyelitis tarnished or blurred the plans previously outlined and served to feed the political crises suffered by Peronism in 1955 and by Batllism three years later.

The onset of polio in Argentina, during the heyday of Peronism, alternated from a 10.6 rate in 1943 to a low rate of between 3.0 and 5.0 cases every 100,000 inhabitants, without any particular action being taken to bring the rate down. But in 1953 there were a total of 2,579 cases, which constituted a rate of 14.0 per 100,000 inhabitants. The two following years saw rates of between 2.0 and 4.0, which brought some relief to the authorities, who were accused by the opposition of suffering from political paralysis on account of the absence of reaction they showed in the face of the disease. In fact, although hospitals had enough beds for polio patients, technical and human resources were scarce and it took a long time for the government to bring them together in specific, specialized spaces, at least within the frame of the State agencies. This is why the year 1943 saw the creation of ALPI, the association against infantile paralysis, founded by Dr. Marcelo J. Fitte. This was the sole private clinic which treated patients with motor disabilities and with polio handicaps entirely for free, thanks to community aid exclusively.

In mid-twentieth century and as a consequence of the worsening of the polio outbreaks both in Argentina and Uruguay, comprehensive rehabilitations centers arose to cater to the need for recovery of the after-effects of polio. These institutions were directly linked to the rehabilitation boom which began in the post-World War II period, spurred by the outbreaks of the 1940s and 1950s. ${ }^{17}$ By that time, some physicians considered that rehabilitation in the case of polio was not a therapeutic technique but rather "a group of methods that allowed the lessening of all kinds of alterations in movement - handicapped patients to ease their integration or reinsertion into social life". ${ }^{18}$

But while these therapeutic changes were introduced, in 1955 and a few months after the military coup that ousted Argentina President Juan Domingo Perón, the Salk vaccine was introduced. Developed by Dr. Jonas Salk, this vaccine introduced a small amount of the virus into the body, which later developed antibodies and an ability to combat the more powerful strains of the disease. Its appearance generated an atmosphere of confidence and the purchase of consignments was announced while different publications and conferences served the purpose of spreading the importance of the vaccine. However, both in Argentina and in Uruguay, the worst was yet to come.

17 A. Amate, A. Vazquez. Evolución del concepto de discapacidad. Discapacidad, Lo que todos demos saber. Organización Panamericana De la Salud, Publicación Científica y Técnica No $616,3-7$.

18 Bravo E. Cuestiones médicas y sociales que plantea la organización de un Centro de Rehabilitación de niños afectos de enfermedad motriz. Madrid: Servicios de Protección Maternal e Infantil, Dirección General de Sanidad; 1958. 
In 1954, Uruguay suffered 85 cases (a rate of 3.3 per 100,000 inhabitants), most at the end of the year, in December, and the number of cases rose in early $1955 .{ }^{19}$ The 28 cases reported in December 1954 had doubled by January 1955 until a high was reached in March: 211 cases. Out of a total number of 524 cases in that outbreak, 255 cases belonged to Montevideo (the capital of Uruguay) and 269 to the Departments. The highest sickness rate was in infancy $(44.4 \%$ under the age of three). ${ }^{20}$

Where did the outbreak originate? Judging by the existing records, the first cases did not appear in the capital city but in the locality of San José, which, as can be seen in the period map, lies close to the Uruguayan capital of Montevideo.

Map 2. Distribution of poliomyelitis cases in different areas of Uruguay, December 1954 - May 1955

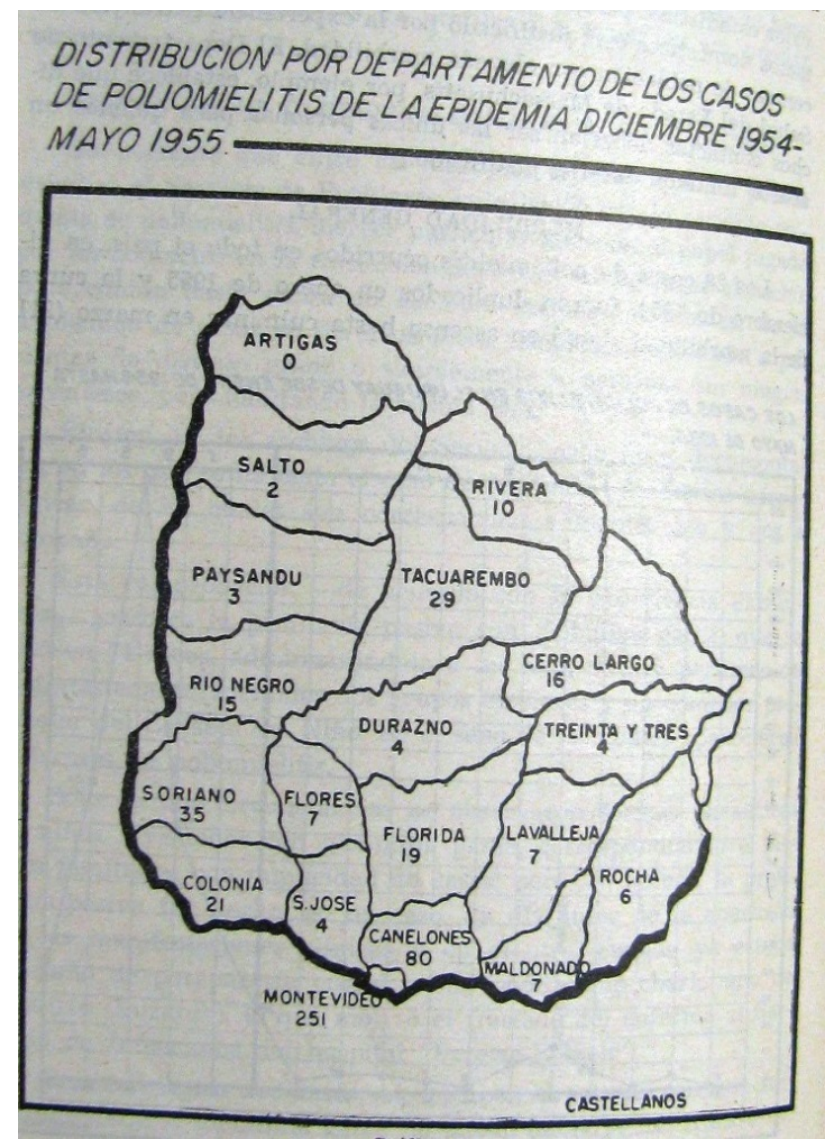

Source: Gómez Malaret, Simón and Osvaldo Luzardo, Poliomielitis: Epidemia de 1954-1955 in: Archivos de Pediatría del Uruguay, Año XXVII, Agosto de 1956, n 8 p. 512.

19 Gomez Malaret, Simon and Osvaldo Luzardo. Poliomielitis. Epidemia de 1954-1955 in: Archivos de Pediatría del Uruguay, Año XXVII, Agosto de 1956, n 8, p.512.

20 Gómez Malaret, Simón and Osvaldo Luzardo. Poliomielitis. Epidemia de 1954-1955 in: Archivos de Pediatría del Uruguay, Año XXVII, Agosto de 1956, n 8, p. 510. 
Map 3. Poliomyelitis cases in San José, Canelones and Montevideo

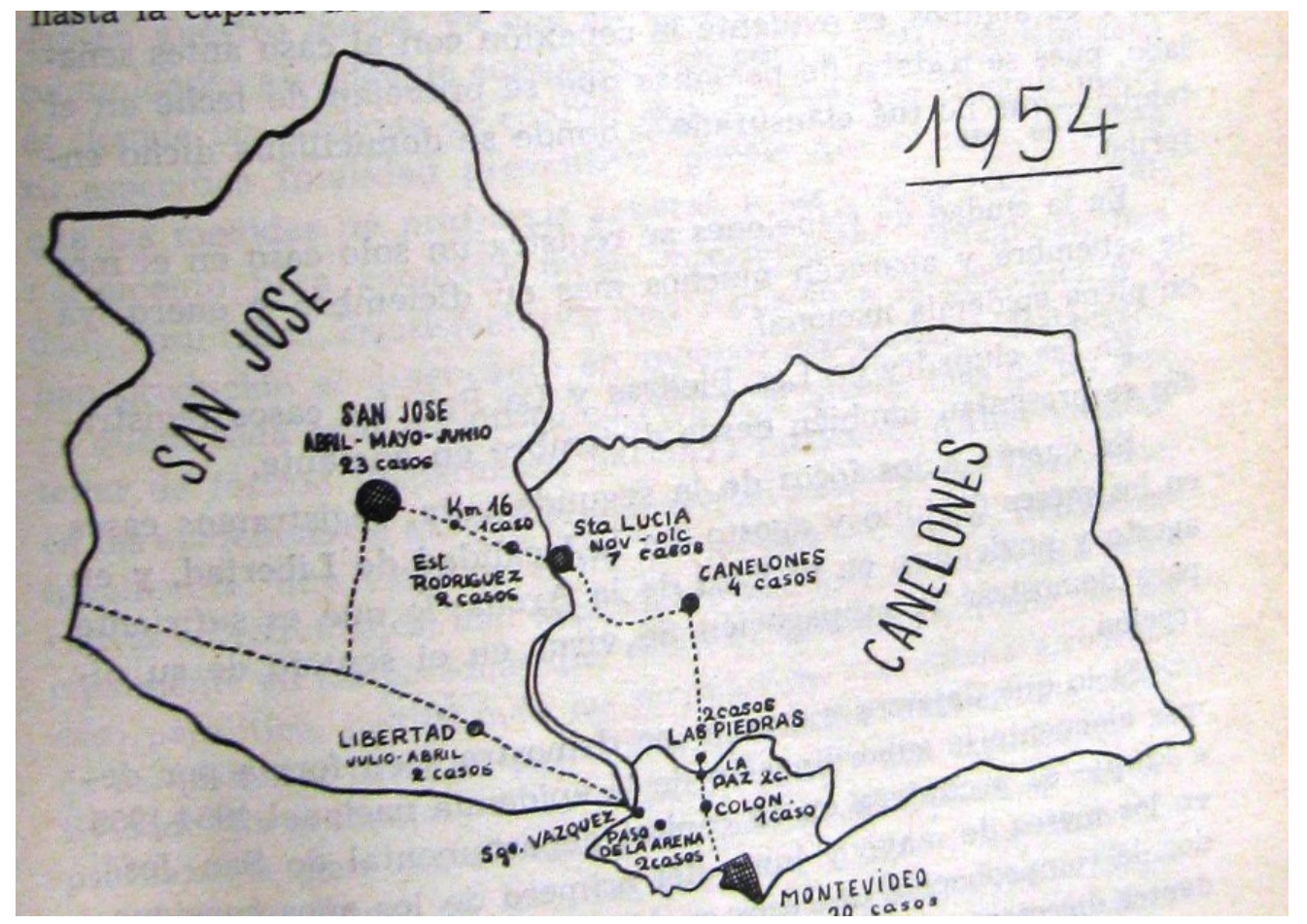

Source: Gómez Malaret, Simón and Osvaldo Luzardo, Poliomielitis: Epidemia de 1954-1955 in: Archivos de Pediatría del Uruguay, Año XXVII, Agosto de 1956, no 8 p. 512.

Transmission was effected by “...people coming directly from San José ....to Montevideo...spreading contagion to other localities" because...it has greater communication with each one of the Departments..." as can be seen in the following chart.

This time, the State did not react, did not establish sanitary containment lines to prevent the disease from spreading from one locality to the next. Considering that the cycle began in rural communities and that it was detected in its early stage (the cases were reported immediately), the rural communities or its sick members could have been placed in isolation to prevent contact between affected and healthy communities. What is worse, there were double cases in family groups ${ }^{21}$ since at that time there was little if no chance of getting the Salk vaccine, measures were basically palliative and were based on passive preventive treatment through the use of gamma globuline shots. The problem was that they were administered too late ("...they use was delayed...”) since it was prescribed for domestic contacts to prevent contagion within the households.

The rate of incidence of the disease was of 25 cases every 100,000 inhabitants in Montevideo; 178 cases every 100,000 inhabitants in the countryside and 20 cases out of 100,000 in the country at large. Clearly, the countryside was struck hardest. In

21 Gómez Malaret, Simon and Osvaldo Luzardo. Poliomielitis: Epidemia de 1954-1955, in: Archivos de Pediatría del Uruguay, Año XXVII, Agosto de 1956, n 8, p. 512. 
1956 there was a drop in the disease which "... a total of 71 cases of poliomyelitis a recorded, 18 of which belong to the capital and 63 to the rest of the country..." ${ }^{22}$ It was precisely in that year that, as we shall see below, vaccination with inactive virus of the Salk type, was begun.

It is a unique case that, according to the Medical Records "...in Uruguay the greatest tribute to the disease lies with the less benefitted classes of society, unlike was allegedly happens in other countries. Sixty percent of the cases fall within the regular bad classification and forty percent to good very good...". ${ }^{23}$ This has a bearing with what has been explained above: the countryside was struck hardest and had few health care resources.

What was going on in the borders of Uruguay? In the last months of 1955, in an Argentina which had ousted Peronism from power, there were 435 cases, which meant a rate of 2.3 every 100,000 inhabitants, ${ }^{24}$ reported by the press and denied by the new authorities, who had in the past condemned the previous government for denying the appearance of the disease. The following year, under the de facto government of Pedro Eugenio Aramburu, the figure grew to 6,496 cases, or a rate of 33.3 cases every 100,000 inhabitants. ${ }^{25}$
....During a span of around two months, the health authorities, while admitting the existence of cases, denied that it was an epidemic and sought to ease the concern caused by alarmist reports which exaggerated the situation and produced great anxiety in those household where there were children. At last, seeing the gravity of the disease and the repetition of medical statements to the effect that there were more than fifty cases per day, the Government finally admitted that there was an epidemic... ${ }^{26}$.

The foreign and national press reported the situation, stating that the first cases arose in the area of Greater Buenos Aires, causing "...true alarm in the country... ${ }^{27 \text { " due }}$ to the extension of and death rate produced by the outbreak.

22 Luzardo, Osvaldo. Epidemiología de la poliomielitis en Uruguay. Posteriormente a la epidemia nacional 1954-1955 ...in: Archivos de Pediatría del Uruguay, p. 32.

23 Gómez Malaret, Simon y Osvaldo Luzardo. Poliomielitis: Epidemia de 1954-1955, in: Archivos de Pediatría del Uruguay, Año XXVII, Agosto de 1956, n 8, p. 512.

24 Figures from "Epidemiología de la poliomielitis formas paralíticas-año 1958”, Ministerio de Asistencia Social y Salud Pública. Sección de Estadísticas Vitales. Buenos Aires, Argentina, 1959.

25 Figures from "Epidemiología de la poliomielitis formas paralíticas-año 1958", Ministerio de Asistencia Social y Salud Pública. Sección de Estadísticas Vitales. Buenos Aires, Argentina, 1959.

26 ABC newspaper"Aumenta de manera alarmante la epidemia de poliomielitis. Once defunciones en una sola jornada. Estados Unidos y otros países envían a la Argentina personal científico y material sanitario". Sábado 17 de marzo de 1956, p. 899.

27 ABC newspaper "Aumenta de manera alarmante la epidemia de poliomielitis . Qnce defunciones en una sola jornada. Estados Unidos y otros países envían a la Argentina personal científico y material sanitario" Sabado 17 de Marzo de 1956 p. 899. 
With the 1956 outbreak, the report established by the World Health Organization in November 1955 became of central importance. On that occasion, the WHO summoned a group of international experts to examine the several aspects related to poliomyelitis. One of the aspects highlighted by the group was the convenience of using the vaccine, above all its distribution according to age groups, since paralytic poliomyelitis was more severe in adults.

Figure 1. Newspaper La Nacion

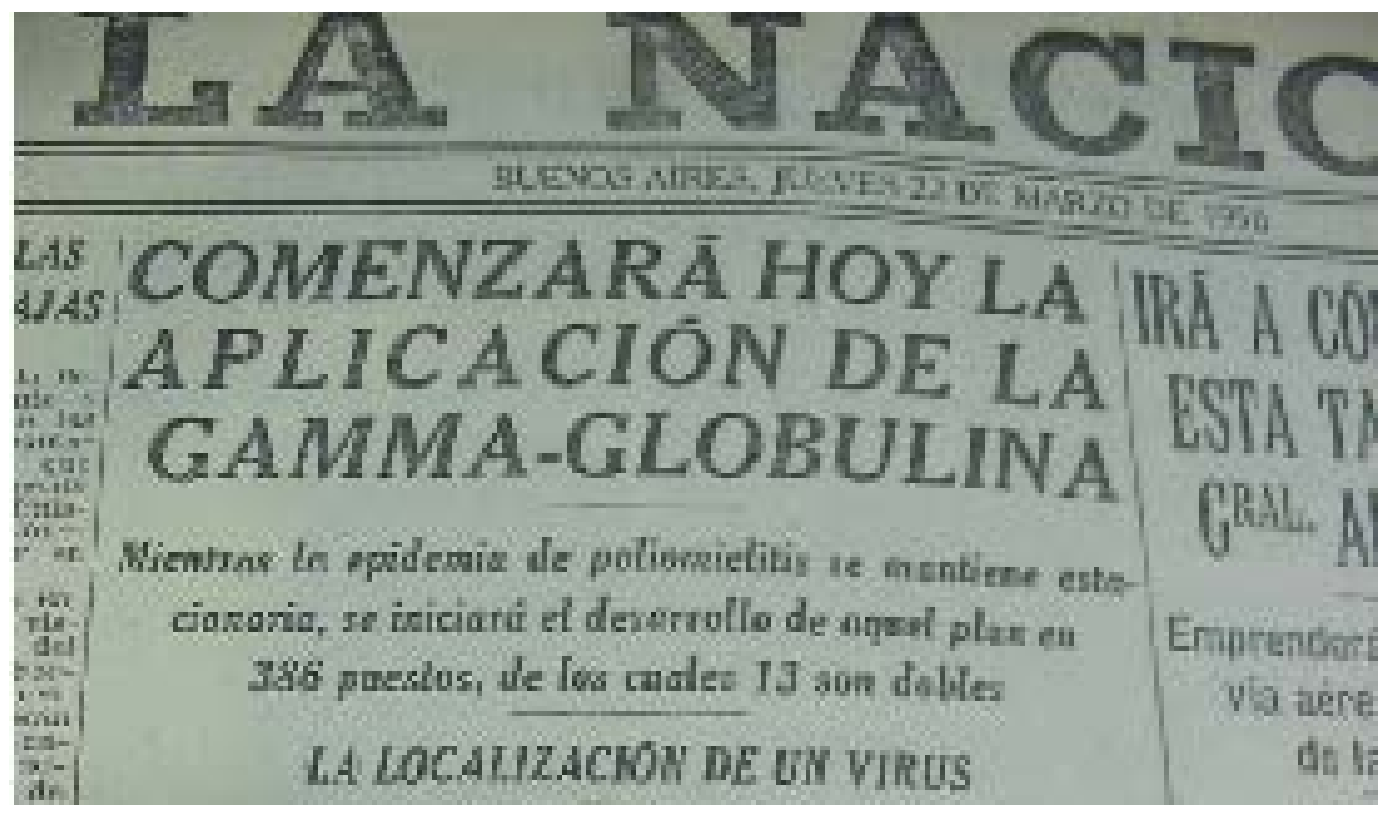

But availability of the Salk vaccine was complicated in these countries, unlike what happened in Europe, where most of the countries were using locally produced inactive vaccines, although they sometimes had to import them from the United States and Canada to cover the demand..$^{28}$ Argentina and Uruguay had to import them, which not only increased the costs of purchase but also slowed it down. This is why the Revolutionary Liberation government of Argentina, in the early months of 1956 and owing to the absence of Salk vaccine consignments, began administering the first gamma globuline shots in schools in March, ${ }^{29}$ with the intention of immunizing 300,000 children between three months and five years of age.

28 Porras, María Isabel, María José Báguena, Rosa Ballester and Jaime de las Heras. "La Asociación Europea contra la Poliomielitis y los programas europeos de vacunación". In: Revista Dynamis, 2012, 23(2):287-310.

29 La Nación newspaper, jueves 23 de marzo de 1956, p. 1. 


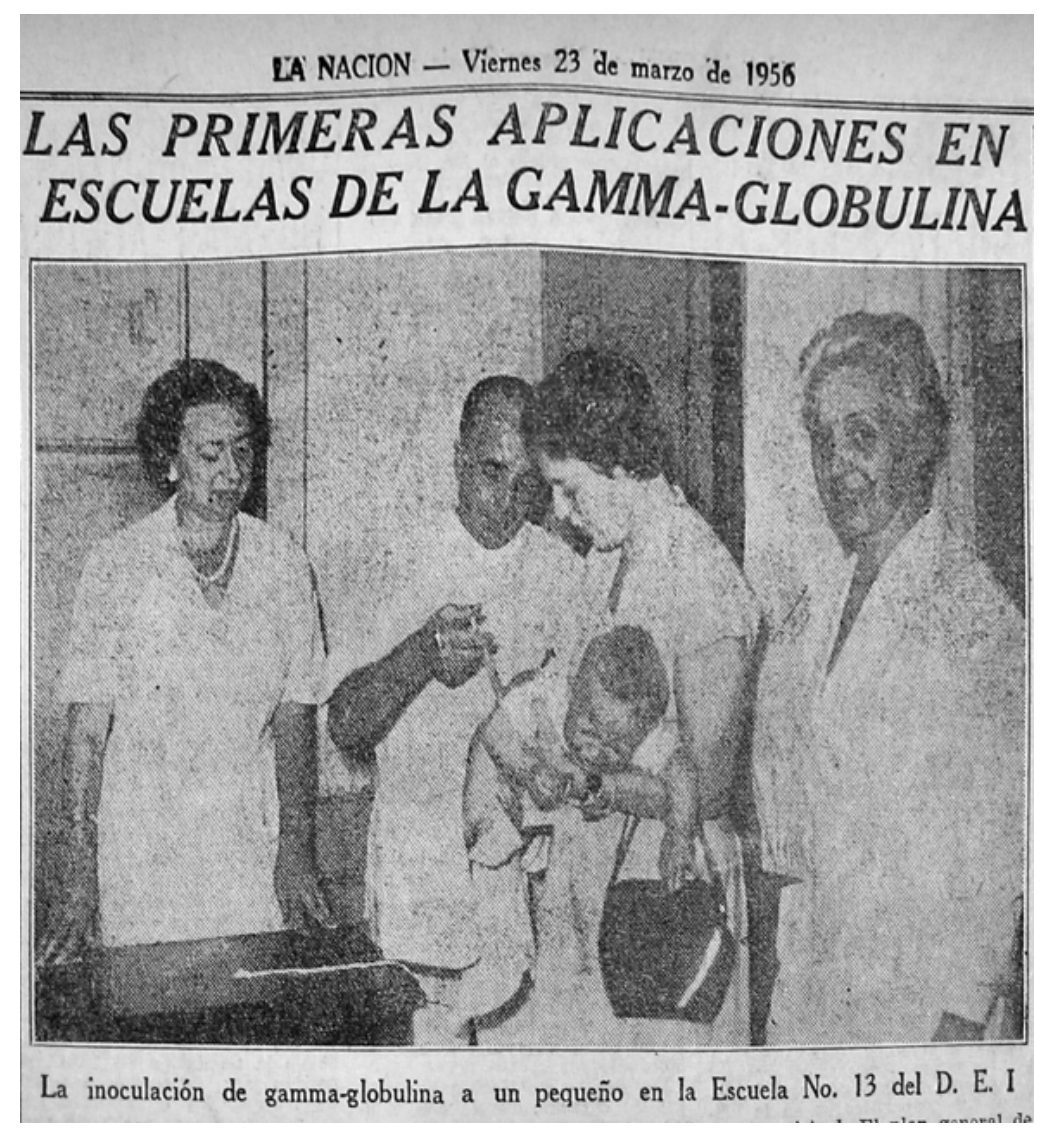

Gamma globuline was used because, according to the Argentine authorities "...at present it is a comprehensive solution sought to annul the epidemic...", with the intent of creating defenses in the younger ones ${ }^{30}$ in order to counteract the effects or the development of the disease, while awaiting the arrival of consignments of Salk vaccines which took place after the main outbreak in the summer season. This is why it was in 1956 that the first Salk inoculations were carried out in both countries, increasing in number the following year. ${ }^{31}$

In Uruguay, vaccination with Salk-type inactive viruses was carried out on limited areas of population, at a moment when, given the sudden fall in the number of cases, concern had lessened and given way to lack of interest, which was also a consequence of the doubts perceived regarding effectiveness or consequences of inoculation.

30 La Nación newspaper, 14 de marzo de 1956, p. 1.

31 The Salk vaccine or inactive poliovirus vaccine (IPV) is based on three reference varieties: Mahoney (poliovirus type 1), MEF-1 (poliovirus type 2) and Saukett (poliovirus type 3). The viruses are cultivated in Vero cells from monkey kidney epithelial tissue and are later inactivated through the use of formaldehyde. The Salk vaccine provides immunity mediated by immunoglobuline in the bloodstream, which prevents the progress of the poliovirus infection to a viremia and protects the motor nerve cells. In this manner, the risks of bulbar polio and of postpolio syndrome are eliminated. However, since there is no protection to the intestinal membrane, people who have received the Salk vaccine may be carriers and transmit the disease to nonvaccinated individuals. 
Besides, this perception was increased by the negative experiences such as that the vaccine "....brought the disease upon 200 people who were immunized with defective material...", ${ }^{32}$ According to Ministry of Public Health official figures, use of the Salk vaccine was relatively scarce and shows a fall towards the end of the decade, as can be seen in the following chart:

Table 2.Number of people who received three or more doses of Salk vaccine

\begin{tabular}{|l|c|}
\hline Year & People Vaccinated \\
\hline 1956 & 0 \\
\hline 1957 & 26.425 \\
\hline 1958 & 18.805 \\
\hline 1959 & 14.657 \\
\hline 1960 & 8.499 \\
\hline
\end{tabular}

Source: Albert Sabin "Planeamiento de la eliminación de la Poliomielitis en Basil, Uruguay, Argentina y Chile" in: Boletin de la Oficina Sanitaria Panamericana, Washington, 1962 p. 502.

In 1958, with the onset of a new epidemic, the Montevideo Department Council began anti-polio oral vaccination campaign with weak Cox virus strains produced by the Laderle Laboratories. Up to that moment, two types of vaccines had been used in the world: the injectable vaccines with dead or inactivated viruses (Brodie, Kolmer, Lepine and Salk) and the oral vaccines with weak live viruses (Cox, Koprowski and Sabin). The Brodie and Kolmer vaccines were soon abandoned. By then, reports in Europe showed a rise in the use of the Sabin vaccine following the reports on the result of the application of this vaccine in the Soviet Union, as presented in the $\mathrm{V}$ International Congress (1960). ${ }^{33}$

In the late 1950s, some 325,000 inhabitants of Montevideo, of all ages, had received the vaccine. However, there were 87 cases of paralysis in Montevideo, where the population made up more than one third of the total population of Uruguay, and 75 cases in the areas where no vaccines had been administered and, in some cases, in localities where some vaccines had been used but on a very small number of the population..$^{34}$. This rise, in the midst of the progress in the vaccination program, can be explained by limiting factors, such as lack of coordination and absence of state

32 La Nación newspaper. Buenos Aires, 1956.

33. Luzardo O. Epidemiología de la poliomielitis en el Uruguay posteriormente a la epidemia nacional 1954-1955.En:Arch. pediatr. Urug.34(1): 32-42; 1963.

34 Tercer Informe del Comité de Expertos en Poliomielitis, Serie de Informes Técnicos no203, OMS, Ginebra, 1960, p.15. 
planning to prevent the disorganization shown in this stage. Such lack of organization can be ascribed to the political and institutional situation Uruguay was undergoing at the time, since in 1958 the Partido Nacional won elections, displacing the Partido Colorado, which had governed for 93 years. Thus did neo-Batllism come to an end.

On the other hand, we must point out that the Salk vaccine showed its usefulness in preventing polio paralysis, but its application had some drawbacks. The high cost of the vaccines made it difficult for the states to buy them, so they had to rely on voluntary contributions made by citizens in response to campaigns organized by physicians or non-profit public welfare organizations. Besides, each individual had to receive three doses which had to be taken throughout a long time span of at least eight months for the immunization to be effective, with the added disadvantage that the vaccine protected those who had been vaccinated but did not prevent polio infection, as it did not prevent multiplication of polioviruses in the bodies of the immunized individuals. ${ }^{35}$

The Committee of experts in poliomyelitis of the World Health Organization, after considering the improvements of the times, recommended in July 1957 that the oral vaccine should be used in areas with endemic infantile poliomyelitis or at the onset of an epidemic, or during its development. In the last case, the recommendation was based on the fact that, as explained above, the Salk vaccine did not have immediate effect nor did it interrupt the transmission of the virus. On the other hand, the oral vaccine acted speedily, produced antibodies in a few days, and, by acting on the intestine, prevented intestinal multiplication of the epidemic polioviruses. $^{36}$

These recommendations, added to those made by the Pan American Health Organization to similar account, influenced different countries. Uruguay was a pioneer, using Cox strains in 1958. In the early 1960s (1960-61) there was an increase in polio cases, which was due to the characteristics of the immunization process, in which the size of the vaccinated population was neither large nor encompassing, unlike what happened later, with the first Sabin oral vaccination campaign of $1962 .{ }^{37}$ The case of Uruguay is contemporary with that of the United States, and it was Uruguay and Chile, within Latin America, who first experimented with changes in vaccination campaigns early on in the 1960s. ${ }^{38}$ Between 1962 and 1964 there were massive oral vaccination campaigns against poliomyelitis. In the first campaign, $80 \%$

35 An individual vaccinated with the Salk vaccine may carry in his intestines a large quantity of polioviruses, which reproduce in the same way as in those people who have not been vaccinated.

36 Bacigalupi, J.C. Estado actual de la vacunación antipoliomielítica por vía oral, con virus vivos atenuados. In: Arc. Pediatr. Urug. 34(2-3):100-111 and 175-184; 1963.

37 The OPV is an oral vaccine with weak live viruses, prescribed at months 2, 4, 6 and 12 with an additional dose at the age of five. Uruguay began this massive campaign with OPV in 1962.

38 Las condiciones de salud en las Américas. 1961-1964. Publicación Científica no 138. Agosto de 1966. OPS/OMS. Washington, p.63. 
of the country's population under the age of twenty was vaccinated; in 1964 the new generations were immunized and the 1962 group was vaccinated again. Children under three years of age were intensely targeted and all children up to the age of fourteen were vaccinated again.

The results were clear and of the few sporadic cases reported in 1970, most were of children who had not been immunized. ${ }^{39}$

The 1962-64 campaign gave way in 1966 to the DPT and Polio vaccination plan, which used the polyvalent vaccine against polioviruses I, II and III, in use up to the 1980s. ${ }^{40}$

Argentina used the Salk vaccine up to 1964 , when it began to use the oral Sabin vaccine. This change brought about a fall in the number of cases of the disease (the lowest rate can be found in 1967 with a rate of 0.3 every 1,000 inhabitants). But the later lack of continuity in the vaccination programs triggered off a rise in cases from 1968, with an outbreak which lasted until 1974.

The development of massive vaccination programs from 1971, added to an intensified watch system, allowed the disease to be controlled by 1977. Between 1978 and 1984 there were isolated outbreaks, most of them belonging to type 1 (the most severe type). Since 1984 no cases of polio have been recorded in Argentina. In 1984 the last case was recorded in the town of Orán, province of Salta and since then there have been no recorded cases of wild viruses in the country.

\section{By Way of a Conclusion}

The previous pages have analyzed the course of poliomyelitis in two South American countries, and, through a multidimensional approach have explained two welldefined historical moments: the early twentieth century and the period which began in mid-century. As regards the latter, infantile paralysis served as a catalyzer of different aspects of the two countries' social reality, since it brought to the forefront the limits of medical science, which, until the appearance of vaccines, left the state agencies without the tools to successfully cope with the epidemics. It also served to show that although operative forms of the welfare state were present in both countries involved in the study, these were not fully operational and were partial versions which gave rise to different institutional universes and different interventions, at least

39 XII CONFERENCIA SANITARIA PANAMERICANA. XXII REUNIÓN DEL COMITÉ REGIONAL WASHINGTON D.C., E.U.A. SEPTIEMBRE-OCTUBRE 1970.

40 The National Vaccine Plan is postponed until 1981, when law 15272 established compulsory vaccination against eight diseases (tuberculosis, tetanus, whooping cough, diphtheria, poliomyelitis, measles, rubella and mumps). Its application by the Ministry of Public Health gives way to the present Broadened Immunizations Program, national counterpart to the program established for the region by the Pan American Health Organization. 
regarding vaccination campaigns. The absence of a State of Commitment towards the paralyzed children patients was a steady component as was the citizens' response: through different events and/or organizations, citizens organized ways of providing the vaccines and created specific aid facilities, both of which the state agencies did not provide, such as the Anti-Poliomyelitis Centers. These new civilian actors, who arose within a robust State model which aspired to centralize and regulate the provision of health care services, were the ones who raised awareness to the fact that the notion of universal coverage for their children's ailment did not exist. This lack of coverage was evidenced not only by the absence of policies for the treatment of children who had survived polio, but also, and principally, by the fact that the existing public sanitation models were not incorporating the changes in the concept of what it meant to be handicapped or the new ideas surrounding child disability, an idea which included both physical and social rehabilitation.

Adriana Carolina Alvarez is researcher at the National Council of science and technology (CONICET) and the Centre for historical studies (Cehis) in Buenos Aires Argentina; Professor of the Faculty of Humanities of the National University of Mar del Plata. 


\section{References}

Alvarez Adriana "El impacto de los brotes de poliomielitis en las formas de organización ciudadana (Buenos Aires), Revista de Historia de la Medicina y Epistemología Médica V: 1 (2013), 1-13.

Bacigalupi, J.C. "Estado actual de la vacunación antipoliomielítica por vía oral, con virus vivos atenuados", Archivos de Pediatria de Uruguay. 34(2) (1963), 100111.

Birn, A.E., W. Cabella and R. Pollero,"La mortalidad infantil uruguaya en la primera mitad del siglo XX: un análisis por causas del pasado al presente." In VII Jornadas Argentinas de Estudios de Población (Asociación de Estudios de Población de la Argentina), I: 37-154, Universidad Nacional de Tucumán. Tafí del Valle. (Tucumán, 2005).

Birn, A.E., R. Pollero and W. Cabella, "No se debe llorar sobre leche derramada. El Pensamiento Epidemiológico y la Mortalidad Infantil en Uruguay, 1900-1940", Estudios Interdisciplinarios de América Latina y el Caribe 1(1) (2003), 35-65.

Gomez Malaret, Simon and Osvaldo Luzardo. "Poliomielitis. Epidemia de 19541955" Archivos de Pediatría del Uruguay, 27(8) (1956), 512- 520.

Margolis, E., N. Piaza, Organización de la atención médica en el Uruguay. (Montevideo. Nordan, 1989).

Luzardo, Osvaldo, "Epidemiología de la poliomielitis en Uruguay", Archivos de Pediatría del Uruguay, 34(1) (1963), 32-42.

Ortega, Elizabeth; Mitiavila, Myriam Raquel, "Preventismo sanitarista y la institucionalización del Trabajo Social en el Uruguay neobatllista: una indagación genealógica”, Revista Katálysis, 8(2) (2005), 211-224.

Pellegrino, Adela, Caracterización demográfica del Uruguay. Montevideo. UNFPAFacultad de Ciencias Sociales-Universidad de la República, Uruguay. 2003.

Portillo, José, "Historia de la medicina estatal en Uruguay (1724-1930)". Revista Medica Uruguay, 1 (1995), 5-18.

Porras, María Isabel, María José Báguena, Rosa Ballester and Jaime de las Heras. "La Asociación Europea contra la Poliomielitis y los programas europeos de vacunación”. In: Revista Dynamis, 23:2 (2012), 287-310.

Reggi, José "El problema del tratamiento de la parálisis infantil en nuestro país", Segunda Conferencia para el Bienestar del Lisiado. (Buenos Aires, 1946). 